In Gintl's ${ }^{1}$ work on the fusion of bauxite in the electric furnace, some blue patches of corundum were made which showed, on analysis, to consist of $\mathrm{TiO}_{3}, 0.65 ; \mathrm{FeO}, 0.79 ; \mathrm{MnO}, 0.50 ; \mathrm{CaO}$, I.83; $\mathrm{MgO}, 0.35 ; \mathrm{NaO}, 2.07 ; \mathrm{SiO}_{2}$, I2.28; $\mathrm{Al}_{2} \mathrm{O}_{3}, 81.88$. Scoria in the blast furnaces are sometimes blue, and owe their color to the presence of titanium. Titanium, while not found in abundance in any one locality, must, nevertheless, be widely distributed for there appears to be more titanium than carbon in the earth's crust. The titanium oxides grade away in color from the white of $\mathrm{TiO}_{2}$ through blue to purple when you get to $\mathrm{Ti}_{7} \mathrm{O}_{12}$. Attempts to make lower oxides with hydrogen were not successful. Ferric oxide at $1300^{\circ} \mathrm{C}$. to $1350^{\circ} \mathrm{C}$. dissociates into $\mathrm{Fe}_{3} \mathrm{O}_{4}$, or the lower oxide; and the oxides of iron or pure $\mathrm{Fe}$ or any compound of iron become $\mathrm{FeO}$ or, perhaps, $\mathrm{Fe}_{3} \mathrm{O}_{4}$ when fused with corundum. The bead, or boule, is light gray to colorless. Thus iron and titanium when fused with corundum undergo oxidation and reduction. The products that were obtained by this fusion were pinkish. In ordinary solutions, it is well known that every oxidation and reduction is accompanied by change in color. It was this phenomenon that was taking place in the production of the pinkish color. Attempts to get the blue were accompanied with so little success that substances other than iron were used to reduce the titanium. Anatase is blue and has a small percentage of one of the oxides of tin. $\mathrm{SnO}$ and $\mathrm{SnO}_{2}$ with $\mathrm{TiO}_{2}$ showed very little tendency of reduction. The reaction between iron and titanium is very strongly reversible. By simply adding a slight excess of one of the oxides, the reaction can be made to go in the direction of reduced titanium, resulting in perfectly blue corundum boule. The ultimate production of the sapphire in the laboratory left very few technical problems unexplained. This made it possible for the manufacturing department to take up work within a week after the successful conclusion of the research. Little change has been found possible since.

The corundum boule is in every respect identical with the earth-made product. Experts are much less able to tell the synthetic from the earth-made sapphire, than they are the synthetic ruby from the earth-made ruby.

After fusion only part of the iron and titanium oxides are left. Prof. Moses ${ }^{2}$ found only traces of $\mathrm{Fe}_{2} \mathrm{O}_{3}$ and about $\mathrm{O}$. I of I per cent. of $\mathrm{TiO}_{2}$. The analysis of the natural products extant before the synthesis of the sapphire did not show the presence of titanium oxide. Prof. Verneuil ${ }^{3}$ has very carefully analyzed some sapphires from Australia, India and Montana that were perfectly clear under a magnifying glass with the following result in percentages:

\begin{tabular}{|c|c|c|c|}
\hline SAPPHIRE FROM & AUSTRALIA & INDIA & MONTANA \\
\hline Iron oxide & 0.92 & 0.72 & 0.56 \\
\hline Titanium & 0.031 & 0.04 & 0.058 \\
\hline Silica.... & a trace & & 0.10 \\
\hline
\end{tabular}

The unpolished earth-made and the synthetic ruby or sapphire is far from being a thing of beauty. It requires the lapidary's art to bring out their intrinsic qualities. The earth-made products can lend distinction to their wearers and therefore are very highly prized. The synthetic products because of their intrinsic beauty and genuine worth appeal to the many. About 10,000,000 carats of rubies and about 6,000,000 carats of sapphires are produced annually and the demand is growing very rapidly.

IAABORATORY OF INTERNATIONAL OXYGEN COMPANY New YORK

${ }^{1}$ Gint1, Zeitschrift für angewandte Chemie, 1901, p. 1173.

${ }^{2}$ American Journal of Science, 30, 4th series, Oct., 1910.

${ }^{3}$ Compt. rend., 151, 1065, Dec, 5, 1910.

\section{THE GOVERNMENTS' INTERESTS IN THE PULP AND PAPER} INDUSTRY ${ }^{1}$

By MARTIN L. GRIFFIN

RAW MATERIAL

Book paper is almost wholly made from wood by chemical processes, resulting in recovery of only about half its solid contents in pulp. It takes about two cords of wood for one ton of pulp and the wood alone will cost about twenty dollars. This will average about half the total cost of producing bleached pulp at the present time. How important then is the item of wood!

Economies in the process of manufacture have been possible and necessarily effective, but nothing more can be gotten out of the wood than it contains.

\section{EARLY HISTORY OF PULP-MAKING}

In the early days of chemical wood fiber the processes were crude, labor and wood plentiful and cheap. Chemical wood pulp mills were located in such places as Philadelphia, Providence, Derby, Conn., Holyoke (two mills), Turner's Falls. England was a pulp-producing country. These mills went out of business years ago with the receding supply of wood. Ever since, the manufacturers of this pulp have either moved up to the supply or the supply has been brought to the mill, in most cases at a large expense for transportation, or else manufacturers of this grade of paper have altered their plants to manufacture higher grades.

\section{PRESENT ASPECT}

During the past twenty-five years the cost of wood, notably spruce, has doubled; other costs have increased, while the price of paper has remained at a very low level. A great industry in wood papers has been developed at a present capital investment of one hundred and twenty million dollars. Our natural resources in wood have been greatly depleted and converted into paper for the people of the United States at a very low price.

Conditions in the manufacture of this class of papers are fast becoming intolerable even with a protective tariff of $\$ 10.00$ per ton, due solely to the vanishing point of our wood supply. The cost of transportation by rail to out mills is a great burden on our manufacturers, which Canadian manufacturers do not have to bear. Once our mills received their wood supply by floating it down the rivers. Now these resources are largely gone and our Canadian neighbors occupy this point of vantage.

\section{THE STATE OF MAINE}

Maine occupies a peculiar position in this matter. Formerly, well wooded with the most desirable species for lumber and paper and traversed by more large rivers than any other state, whose head waters are great natural reservoirs, its people built up a great industry. It extended its railroads and enlarged its facilities to this end. All of this growth had its source in the natural resources of the state.

\section{GEOGRAPHICAL LOCATION}

Maine, situated as it is at the extreme eastern boundary of the United States, larger in extent than all the other New England states combined, is and forever will be at a disadvantage in doing business in our home markets. There is no possible means of offsetting this transportation handicap to our markets and sources of supply. Some other advantages must exist or else development, so slow in the past, will cease altogether and present industries, of which I am writing, must die out. And I say, when the pulp and paper industry of Maine wanes and finally dies, as it inevitably will within the next twentyfive years if matters are allowed to take their present course, there will be no other to take its place. What motive, what

1 Paper presented before the Maine Section of the American Chemical Society, Auburn, March 19. 1913. 
incentive, or what object is there to encourage manufacturers to come to Maine? Transportation must be had, it is handicapped; coal must be had, it is costly; of natural resources in minerals, they are very limited; of power there is at present a surplus and an abundant opportunity for development, but at present prices it offers little inducement, and power without customers for it has no value. It is idle to talk about conservation of water powers, with no market to take it, and do nothing but talk about conserving the only means by which such power may possess great and lasting value.

\section{WHAT MAINE IS BEST FITTED TO DO}

Aside from its possibilities in agriculture and minor resources, its great potential natural wealth is in its great rivers, lakes and power therefrom and woodlands. Its one great industry is the pulp and paper business. They are wonderfully adapted to each other and either will languish without the other. Rational harvesting and conservation of our present supply, and reforestation, along our great water courses, at the earliest date, will alone preserve this great industry to the state and nation. By so doing the most beneficial results will follow to our people. The wooded areas will conserve the tributary sources of our rivers, make permanent our power from them, and in time the rivers will bear the forest products to our mills at trifling cost.

\section{HOW THIS MAY BE ACCOMPLISHED}

The growth of forest woods is very slow, so slow that one generation cannot hope to profit from its own initial investment in tree planting. It is not an annual growth. There is, therefore, no incentive for the individual to plant forest trees, and there is little for the average corporation. The natural resources of our state and nation, in forest and stream, represent a large unearned increment of wealth, which does not rightfully belong to anybody: it belongs to all. Unlike the vast unearned increment of land values in our great cities, in the hands of a few, which should be equalized with society which created it, these values in virgin woodlands have been distributed to all our people with a lavish hand, through the paper mill and press. Great as has been the value of the discovery of printing and the printing press, they would have had no value without paper. Point if you will to the large capital invested in this industry; it has been made necessary by the demands upon it. Unlike the business of banking, speculating, mining and smelting and many protected industries, it includes no millionaires. The unearned increment has gone to the people.

If our state and nation would desire to preserve this business to itself, it must coöperate to conserve what we have left and proceed at once to a practical plan of reforestation, and the regulation of the harvesting of wood. In this I would include all useful woods, and those from which useful products are obtained.

Unless we do this, we may, for a time, obtain the balance of our increasing needs, from foreign sources, at possibly some concession in price. We know, however, that as soon as we cease to be a competitor, we will no longer pay competitive prices. The results of this policy would be the loss of our natural resources, the depreciation of our water powers, the ruin of the larger part of a great industry; the profits of labor, the source of all acquired wealth; and the final increased cost of this commodity in the near future.

\section{WHO OUR COMPETITORS ARE}

Germany and Scandinavia with their rational system in forestry will always probably have a surplus, and in any case will necessarily sell in the highest market. At present and for some time to come, Canada will be the chief menace to this industry in our own country. A few years ago Canada's acquired resources were limited; her natural, very great. Development in processing pulp and paper has been largely done by us. Our architects have planned Canada's great mills and our machinery builders are furnishing a large part of the equipment. We are pioneers everywhere in building and equipping the largest and fastest running paper machine in the world.

It results, therefore, that Canada has to-day all we possess and large resources in wood which we no longer have. The larger part of our wood now comes from Canada and it requires skilful diplomacy to get it.

\section{SUBSTITUTES FOR WOOD}

There is a popular view, which has been erroneously fostered by our government, that there are exhaustless resources of waste fiber in our country, suitable for paper, and a substitute for wood. I once thought so myself. It is very natural to think that the discarded stalks of sugar cane, corn, cotton, rice, flax and other plants, which mature annually, would prove an abundant substitute for wood. These have all been exploited for twentyfive years to my personal knowledge with no visible results. A plant has one main function to perform-it is to flower, fruit or make stalk. Its other functions are subordinate and produce only by-products. No by-products can be substituted for the main product. The stalk is the main product of the forest tree. No other raw fibrous material is so rich in cellulose; no other lends itself so easily to paper mill processing. It has no seasons of harvest, does not require curing, does not easily decay, requires no packing and may be stored best in the rivers. All these waste stalks are pithy, bulky and perishable and would require much labor to gather, pack and ship. These are but a few reasons why we may expect no practical results from this source. Wood fills a place no other material can. There is no substitute for it.

\section{WHAT THE GOVERNMENT SHOULD DO}

First, it should protect this industry not because we pay our laboring classes more-this is now a worn-out argument and the difference is not worth talking about-nor because there is a trifling duty upon a few chemicals we do not import. There is a duty of $\$ 2.50$ per ton on china clay which should be free, as it does not exist in our country, but this is not a burden. The paramount reason why this great industry should be protected is because the vanishing point of our raw material in wood is coming nearer every year. Given its raw material on equal terms with other countries, it needs no protection. This protection should be equal to the difference in the cost of wood laid down at the mills. It would be better to make it more than this and to use the entire revenue so derived in the work of reforestation.

Second, the state should protect its visible supply by putting a tax upon all timber cut at so much per thousand feet as a renewal and depreciation fund, to be used coopperatively, by which I mean to include all who cut timber for profit. There should be coöperation and joint responsibility to give back to the soil, for the benefit of those who come after us, their share of the unearned increment in timber values we have not earned.

I advocate, therefore, the levying of a duty by the federal government upon all imports of wood products, either as paper or to be used in the manufacture of paper, equivalent to $\$ 5.00$ per cord of $128 \mathrm{cu}$. ft., and that the revenue, therefrom, be devoted to reforestation under a rational scheme of distribution and control.

This equivalent would amount to:

$\$ 5.00$ per ton on mechanical ground wood.

$\$ 6.25$ per ton on common news.

$\$ 10.00$ per ton on chemical wood pulps.

$\$ 10.00$ per ton on chemical wood papers.

Also the levying of a tax by the several states on all timber cut for profit, the proceeds of which to be devoted to conservation and reforestation within their own boundaries.

The wood pulp paper industry once thriving in New England, Pennsylvania, New York, Ohio, Michigan and Wisconsin, is 
now flitting about the international boundary and will soon vanish to the other side unless heroic means are taken speedily to preserve this industry to our home market, the greatest in the world.

RUMFORd FALLS, MAINE

\section{THE TRAINING OF THE FERMENTOLOGIST}

By CARL A. NOWAK

Received March 14, 1913

The fermentation industries are constantly in need of university-trained men. These are difficult to obtain. It appears that at present there is no university in the United States which has outlined courses of work suited to the requirements of students wishing to enter the fermentation industries, not as brewery managers or brewmasters, but in the capacity of technical experts, chemists, chemical superintendents, or as instructors and chemists at the recognized technical colleges or brewing institutes.

These brewing institutes, which are usually maintained in connection with technical laboratories, also known as scientific stations for brewing, require men capable of undertaking, besides teaching, also analytical and research work pertaining to the fermentation industries. Some of the breweries and malthouses have, to some extent in advance of the viticultural establishments, learned to appreciate the value of scientific control; they possess their own laboratories, and they need chemists and chemical superintendents.

The scientific stations for brewing are the result of a more or less general demand on the part of the entire brewing industry for laboratory control of the different brewing operations. Such outside control becomes especially important and valuable when the establishment of a private laboratory in a brewery does not appear feasible, owing to the large expense of installation and still greater cost of maintenance. Membership in these stations is established on the payment of a certain sum a year, in consideration of which the station undertakes to assist the member.in controlling the working conditions by frequent tests, analyses and reports covering the raw materials and products.

The analytical work required of these institutes covers water, coal, mineral, general inorganic and food analysis, and general biological work, but is more particularly concerned with such examinations as the analysis and valuation of barley, malt, malt adjuncts, sugars, coloring syrups, hops, and similar rawmaterials used in brewing with which the average college graduate is practically entirely unacquainted.

From this it follows that the future fermentologist is in need of at least some specialized training, especially if he is also called upon to lecture in the technical school in which the practical brewer or manager seeks to acquire a certain amount of scientific training in order to better fit him for a position of responsibility.

The intellectual development and education of the students applying for membership in these courses is of an extremely varied nature, some possessing good high school, occasionally even college education while others, and unfortunately the majority, are so deficient as to lack even the rudiments of mathematics. All ages from $I 8$ to 60 are represented.

To instruct a class of such varied intellectual ability and to present in the short period of six months (the duration of the course) in a clear and lucid manner all the subject matter outlined, only falls short of a Herculean task. Unless this work is entrusted to a conscientious instructor of more than the average college training, preferably one who is also a student of the human mind, the result is bound to spell failure.

The greatest difficulties are encountered in the teaching of physics and chemistry which are the fundamentals of much of

1 Paper presented at the Annual Meeting of the American Chemical Society, Milwaukee, March, 1913. the other work of the brewing student. Few college men have specialized in biochemistry of plant life, which in the case of the brewing student must receive first attention even to the exclusion of some of the most necessary principles of general chemistry. The commonly accepted method of presenting the subject of chemistry is, due to lack of time, entirely out of the question. It appears not only desirable but in some cases it is absolutely essential that organic chemistry be presented before inorganic, and that the chemical laws and theories, if presented at all, be briefly outlined at the end rather than at the beginning of the course. The labor involved in teaching this subject is furthermore materially increased through the lack of any suitable text-book. It has been my experience, especially in dealing with the older men whose minds are far from being easily susceptible to impression, that the graphic method of presentation, wherever applicable, gives the best results.

These brief remarks, I trust, will show conclusively that. the task assumed by the fermentologist is not an easy one, and, furthermore, that to enable him to do full justice to his work specialized training would be an invaluable asset. It may be proper to seek to determine next, what prospects the fermentation industries offer to those specializing in them.

Owing to the lack, at the present time, of any school in the United States in which the young fermentologist can acquire specialized training, it is usually necessary for the brewing institutes to educate their own instructors and chemists while paying them a reasonable salary.

A chemist just graduating from college, and with but little experience, who is expected to teach from 2 to 4 hours a day in the brewery school and to devote the balance of his time to laboratory work either of an analytical or research nature, may demand a salary of at least $\$ 75.00$ per month, usually more, ranging anywhere from $\$ 75.00$ to $\$$ I25.00 per month; that is, it will be conceded a fine salary for a young chemist just starting in business and is also considerably higher than offered in other industries for laboratory or research work. If a man chooses to remain in this line of work, he may eventually receive a good salary. He can also later accept a position at a brewery or malthouse as chemist or chemical superintendent with the possibility of a still greater compensation if he shows capability along technical lines.

For the young chemist, even though he may not intend to remain in the fermentation industries permanently, the experience gathered may become a valuable asset in his later career provided, of course, that he chooses to enter some other organic line of chemical endeavor.

Unfortunately, and unjustly so because there is no sound reason for it, there are men in some of the other industries who consider the fermentologist as inferior to themselves in education and training, possibly based on the erroneous belief that he knows little else than the chemistry of beer. As a matter of fact a man who has been in the fermentation industries for some time has acquired a good chemical training. He must, of necessity, be a good organic chemist, with considerable knowledge along physiological, bio- and colloidal chemistry, branches of the science which play an equally important part in glue and leather manufacture. He has, usually, a good understanding of the correlation of the practical and theoretical work along these lines which offer unlimited possibilities for original work and research of a practical as well as theoretical nature. We only need recall the many intellectual achievements both in chemical and biological science which have resulted from the stimulus to find the meaning of certain of the more important phenomena connected with the science of brewing.

Whether the outlook for the future and the prospects offered the fermentologist warrant the establishment at any of our universities of courses in fermentation is another question. 